\title{
Obituary
}

\section{WILLIAM LLYWELYN PARRY-JONES}

(1935-1997)

William Parry-Jones, who died in July at the age of sixty-two, was Professor of Child and Adolescent Psychiatry at the University of Glasgow and Honorary Consultant to both the Greater Glasgow Mental Health Services Trust and the Royal Hospital for Sick Children, Yorkhill. A most distinguished clinician and teacher, Parry-Jones was also a productive and influential historian of psychiatry.

His interest in the history of psychiatry began while he was a medical student at Cambridge University. When he suggested a historical subject for his MD thesis he was severely discouraged from this unorthodox line of research. Nevertheless he persevered. The quality of the resulting work, The English provincial madhouse and insanity, was such that it won him the Noble Prize (he often joked that the last two letters should have been transposed) for the best MD thesis of the year. He was shortly elected, at an unusually early age, a Fellow of Linacre College.

The research for the MD formed the basis for the publication, in 1972, of his major historical work, The trade in lunacy: a study of private madhouses in England in the eighteenth and nineteenth centuries. In the early nineteen-seventies the history of psychiatry was not the fashionable subject it is now, and the social history of psychiatry was still in its infancy. The trade in lunacy made a very significant contribution indeed to the development of the new field.

Before publication of The trade in lunacy very little was known of the private madhouse and its role in the care of the insane. Parry-Jones' meticulous research revealed that private, for-profit institutions had been the major source of care and shelter for lunatics and idiots, especially pauper ones, throughout the eighteenth and well into the nineteenth centuries. Earlier accounts of the private madhouse had tended to perpetuate a very negative image of the institution, coloured both by eighteenth-century scandals of unwarranted detention and inappropriate twentieth-century sensitivities. Parry-Jones presented a more balanced view - despite many shortcomings and some flagrant abuse, the care provided by the private madhouse was in general humane, if judged by contemporary attitudes towards insanity or social conditions in general. Another service that The trade in lunacy did for the historiography of psychiatry was to highlight the amount of archival material that was available for the study of institutional care in Britain, and to emphasize the absolute necessity for would-be historians of the subject to engage with that material.

In 1972, Parry-Jones was appointed Director of the Department of Adolescent Psychiatry at the Warneford Hospital in Oxford. It was not long before the excellence of that Department was nationally recognized. In 1987, he was elevated to the Chair of Child and Adolescent Psychiatry at Glasgow. Not only did he run a large clinical and teaching department, he played a major role, both as an advisor to the Scottish Office and through the Royal College of Psychiatrists, in the development of child and adolescent mental health services throughout the United Kingdom. He became recognized as an expert on 


\section{Obituary}

the consequences of traumatic experiences upon children and young people. The knowledge he gained from the study of the psychological aftermath of the Lockerbie disaster was later applied in treating refugees from the former Yugoslavia and survivors of the Dunblane tragedy. Professor Parry-Jones' sincerity, wisdom and dignity made him universally respected.

Despite the immense demands of his clinical, teaching, administrative and advisory responsibilities, he continued to be an active medical historian. His years in Glasgow saw publications on the history of eating disorders and on the history of child and adolescent psychiatry. Under his very active supervision, his student Harriet Sturdy undertook a detailed study of the Scottish system for the boarding-out of lunatics. He and Harriet also collaborated on a study of the Scottish private madhouses. A re-issue of The trade in lunacy was in preparation when he died.

This level of workload could not possibly have been sustained without the constant support of his devoted wife and companion, Brenda, who co-authored many of his later papers and published much in her own right. They were a remarkable academic partnership, an ornament to the University of Glasgow and to the history of medicine in Scotland. We are grateful that Brenda and Harriet are currently at work on bringing the new edition of The trade in lunacy to the press.

When I was developing my own interest in the history of anorexia nervosa, knowing of the Parry-Joneses' reputation in this field, I approached them with a degree of diffidence. Their response, far from being proprietary, was enthusiastic and helpful well beyond the demands of politeness. William's only note of censure, mildly expressed, related to the fact that my collaborator and I had chosen to publish in a sociological journal rather than in a medical one, where our study might, as he put it, "have helped educate my narrower clinical colleagues". For William was convinced that historical scholarship had enormous potential as a power for good within medicine. The very forceful conclusions of The trade in lunacy were that psychiatrists might learn valuable lessons from the ways in which mental illness had been treated in the past. He also spoke eloquently in defence of the traditional role of the asylum as a place of sanctuary and care for those without the inner resources necessary to cope with ordinary social life. His and Brenda's work on eating disorders was motivated by the conviction that historical evidence could shed light on the aetiology of those most perplexing afflictions. At a still more fundamental level, William believed that, within the study of the history of medicine, the doctor might encounter and embrace the humane aspects of his or her profession, those aspects indeed of which William Parry-Jones was himself such an exemplary practitioner.

Malcolm Nicolson 